\title{
L929 Cell Response to Root Perforation Repair Cements: an In Vitro Cytotoxicity Assay
}

\author{
Rosana Belchior MIRANDA ${ }^{1}$ \\ Sandra Rivera FIDEL ${ }^{2}$ \\ Maria Aparecida Affonso BOLLER ${ }^{3}$
}

\begin{abstract}
${ }^{1}$ Santos Dumont Brazilian Air Force Dental Clinic, Rio de Janeiro, RJ, Brazil
${ }^{2}$ Dental School, State University of Rio de Janeiro, Rio de Janeiro, RJ, Brazil

${ }^{3}$ National Institute for Quality Control in Health/Oswaldo Cruz Foundation, Ministry of Health, Rio de Janeiro, RJ, Brazil
\end{abstract}

\begin{abstract}
This study compared the cytotoxicity of an experimental epoxy-resin and calcium hydroxide-based cement (MBPc), gray mineral trioxide aggregate (MTA) and white mineral trioxide aggregate (WMTA) using the agar overlay method with neutral red dye. L929 cells were seeded into 6-well culture plates where 48-h set test materials were placed on the agar overlay, in triplicate. Teflon and natural rubber served as negative and positive controls. After an incubation period of $24 \mathrm{~h}$ at $37^{\circ} \mathrm{C}$ in a humidified atmosphere of $5 \% \mathrm{CO}_{2}$ in air, a discolored area around the samples and the positive controls could be observed and measured per quadrant. The mean values were compared and converted into grades to classify the results according to the table of cytotoxicity grades according to the Standard Operating Procedures (SOP) of the Oswaldo Cruz Foundation, Brazil. The nonviable cell areas and the morphological changes in the cells were observed with an inverted microscope. The results showed grade 1 (slight) for the two types of MTA ( $>00.05)$ and grade 2 (mild) for the $\operatorname{MBPc}(\mathrm{p}<0.001)$. All samples met the requirements of the test as none of the cultures showed reactivity higher than grade 2 .
\end{abstract}

Key Words: root perforation, endodontic sealers, cytotoxicity.

\section{INTRODUCTION}

Root perforations allow the root canal system to communicate with the periradicular tissues and may cause the loss of the tooth due to secondary periodontal involvement. The ideal repair material must show good sealing ability in addition to physical, chemical and biological properties. The properties of an ideal repair material have been demonstrated by several studies since Lee et al. (1) presented mineral trioxide aggregate (MTA). Currently, MTA is considered the material of choice for the repair of root perforations.

MTA is composed by tricalcium silicate, tricalcium oxide, silicate oxide and other mineral oxides that are responsible for its physical and chemical properties. An alkaline $\mathrm{pH}$ and calcium release probably stimulate tissue mineralization (2). The major difference between gray and white MTA (WMTA) is the concentration of iron oxide $(\mathrm{FeO})$. The amount of $\mathrm{FeO}$ is extremely reduced in the WMTA (3), while the biological properties of both types of cement are comparable (4-5).

A new experimental epoxy resin and calcium hydroxide based cement (MBPc) has been developed at the Department of Endodontics of Bauru Dental School, University of São Paulo, Brazil as another option to repair root perforations. The ability of the epoxy resin to seal and the biocompatibility of calcium hydroxide have been proven in vitro (6-8) and have shown good results in vivo (9).

Generally, cytotoxicity is the first test used to investigate biocompatibility. The evaluation of new materials using in vitro methods must first be done to avoid unnecessary animal sacrifice. The agar overlay method with neutral red dye allows great sensitivity using the material as it is used clinically, while protecting the cell monolayer against physical damage (10).

The aim of this study was to evaluate the toxicity of gray MTA, white MTA and the experimental MBPc by comparing their effect on L929 cells, using the agar overlay method with neutral red dye. 


\section{MATERIAL AND METHODS}

\section{Test Materials}

Gray ProRoot MTA(Dentsply/Tulsa Dental, Tulsa, OK, USA) and Angelus WMTA (Angelus Soluções Odontológicas, Londrina, PR, Brazil) were mixed in a 1:1 ratio of powder: liquid, and the MBPc experimental cement was mixed in a $3: 1$ ratio of base paste $(0.2 \mathrm{~g})$ : catalyze paste $(0.6 \mathrm{~g})$, according to the manufacturers' instructions. The mixtures were then immediately placed into a silicone mold to prepare uniform pellets $(6 \times 6$ $\left.\mathrm{x} 1 \mathrm{~mm}^{3}\right)$. The cements were allowed to set for $48 \mathrm{~h}$.

\section{Cell Culture}

L929 cells, derived from mouse fibroblasts (ATCC, Rockville, MD, USA), were stored frozen Eagle's minimum essential medium (MEM) with Earle's salts (Sigma Aldrich Corp., St. Louis, MO, USA), supplemented with $20 \% \mathrm{v} / \mathrm{v}$ fetal bovine serum (FBS; Gibco, Grand Island, NY, USA), streptomycin sulfate $(100 \mu \mathrm{g} / \mathrm{mL}$, Sigma Aldrich Corp.), anphotericyn B (100 IU/mL, Sigma Aldrich Corp.), L-glutamine (2 mM, Sigma Aldrich Corp.) and 10\% v/v glycerol into liquid nitrogen at $-70^{\circ} \mathrm{C}$. For use in this experiment, the cells were transferred to $75 \mathrm{~cm}^{2}$ flasks (Costar, Corning, NY, USA) in Dulbecco's MEM supplemented with 5\% FBS and antibiotics and were subcultured.

\section{Agar Overlay Method}

The study was performed according to the Standard Operating Procedures (SOP) of the Oswaldo Cruz Foundation (FIOCRUZ, Rio de Janeiro, RJ, Brazil) (11). Cells were seeded in 6-well plates (Costar) at a density of $2 \times 10^{5}$ cells $/ \mathrm{mL}$. Each well, which had an inner diameter of $35 \mathrm{~mm}$, received $4 \mathrm{~mL}$ of the prepared suspension. The plates were incubated for $48 \mathrm{~h}$ at $37^{\circ} \mathrm{C}$ in an atmosphere of $5 \% \mathrm{CO}_{2}$ in air and $100 \%$ humidity, to allow adhesion and cell monolayer confluence. The medium was removed from the wells and replaced with agar 1.8\% (Bacto; Difco Laboratories Inc., Detroit, MI, USA) added neutral red dye $0.01 \%$, staining the viable cells while allowing diffusion of leachable chemicals from cements. Samples in triplicate, positive (natural rubber) and negative (Teflon) controls on the agar overlay featured the 6-well plates. One well in each plate received the agar only to serve as a cell control.

After an incubation period of $24 \mathrm{~h}$ at $37^{\circ} \mathrm{C}$ in a humidified atmosphere of $5 \% \mathrm{CO}_{2}$ in air, discolored areas could be seen around specimens related to their toxicity. A milimetric paper was placed underneath the plates before pictures were taken with a digital camera (Nikon Coolpix 4300; Kinon, Tokyo, Japan). Then, the areas of nonviable cell were measured per quadrant using Image Tool image-analysis software (The University of Texas Health Science Center at San Antonio, Texas, USA) adjusting the image magnification tool that allowed improved view of focused areas. The milimetric paper allowed calibrating the digital measurement tool. The method evaluated the biological reactions quantitatively, comparing the extension (in $\mathrm{mm}$ ) of nonviable cell areas.

The results were classified according to a 5-point cytotoxicity grading system related to the agar overlay method, according to which grade 2 or lower means satisfactory samples: $0=$ absent cytotoxicity (absence of a zone of lysis underneath the sample; $1=$ slight (zones of cell lysis underneath the sample only); $2=$ mild (zones of cell lysis $\leq 5 \mathrm{~mm}$ from the sample); $3=$ Moderate (zones of cell lysis $>5 \mathrm{~mm}$ and $\leq 10 \mathrm{~mm}$ from the sample); $4=$ severe (zones of cell lysis $>10 \mathrm{~mm}$, but not involving the entire well). In addition, the wells were occasionally examined with an inverted microscope (Nikon Eclipse TS 100; Nikon) to observe cell changes.

\section{Statistical Analysis}

Parametric analyses of data were performed by one-way ANOVA and Tukey's test at 5\% significance level using GraphPad Prism statistical software package (GraphPad Software Inc., San Diego, CA, USA).

\section{RESULTS}

There were statistically significant differences $(p<0.05)$ among the mean zones of cell lysis comparing the cements to each other and comparing the cements to the controls from the respective plates (Fig. 1).

Classified according to the 5-point cytotoxicity grading system, ProRoot MTA and the Angelus WMTAreceived grade 1 (slight cytotoxicity) and the MBPc received grade 2 (mild cytotoxicity). Negative controls were graded 0 (absent cytotoxicity), while positive controls were graded 3 (moderate cytotoxicity). Cell controls showed viable cells during the entire experimental period. 

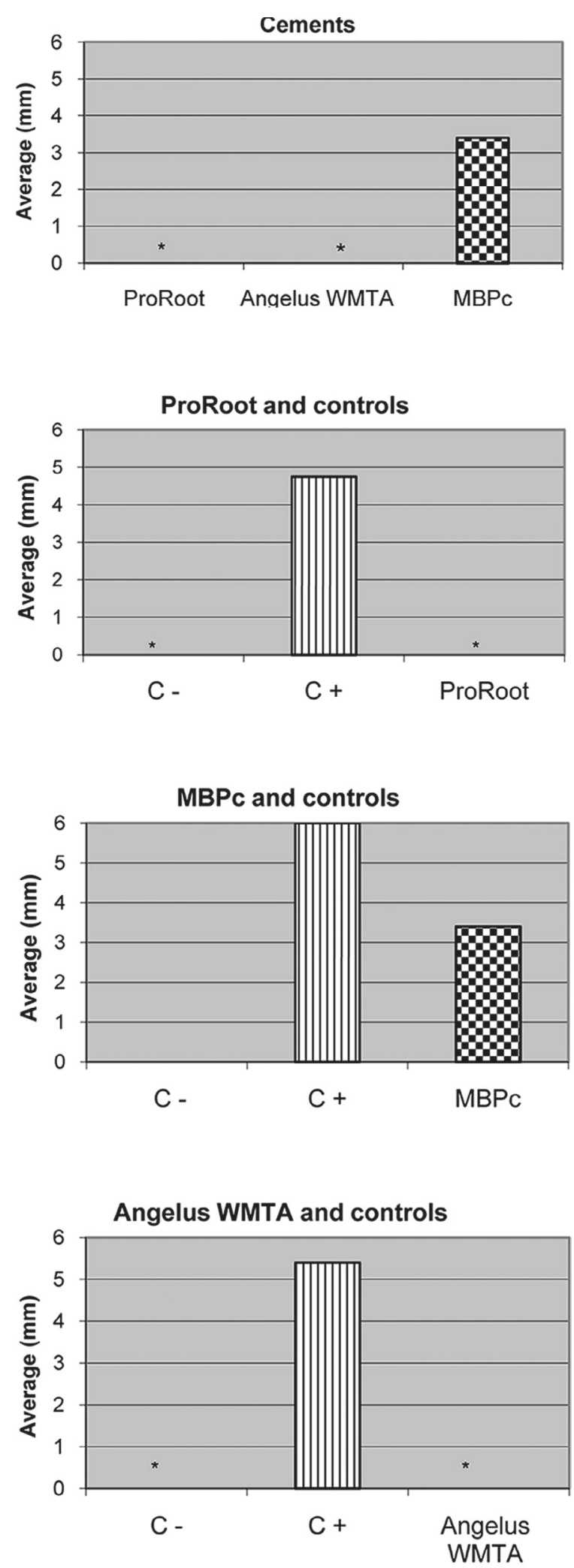

Figure 1. Comparison of the mean zones of cell lysis among cements and among the cements and their respective controls.
When examining morphological changes in the cells with the inverted microscope, ProRoot MTA showed viable cells around the pellets. Dead cells could be observed underneath the material after removal from the agar layer.

A $\times 100$ magnification of an Angelus WMTA well clearly showed 4 different moments in the cell morphology around the cement: cell lysis, rounded cells loosened from the substrate, some morphological alterations, and viable cells with homogeneous cytoplasm in a monolayer (Fig. 2). MBPc revealed the largest zones of cell lysis and morphological cell changes among the 3 cements. Because of this only one section of all wells examined in the study exhibited the different zones within the same filed of view (Fig. 3).

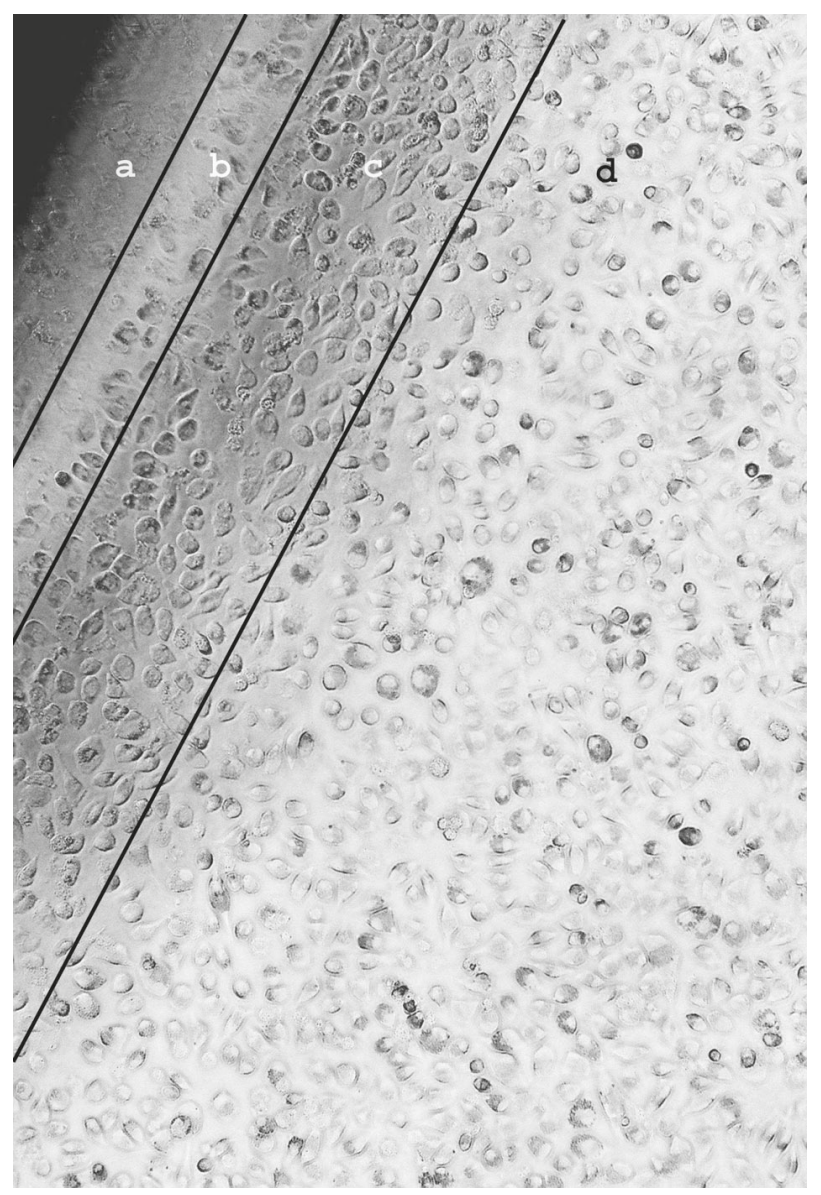

Figure 2. Well 2 of Angelus WMTA: a) cell lysis; b) rounded cells loosened from the substrate; c) some morphological cell changes; d) viable cells exhibiting a homogeneous cytoplasm and arranged in a monolayer $(\times 100$ magnification $)$. 


\section{DISCUSSION}

Studies with established cell lines are used because of the reproducibility of the results, besides they multiply rapidly with an unlimited life span (12). It is interesting to evaluate the reaction of fibroblasts to the materials because those cells are involved with the healing process. The established L929 cell line used in this study is commonly employed in biocompatibility studies $(10,13-15)$.

Using the agar overlay method with vital red dye, Torabinejad et al. (13) recorded a zone of lysis around the samples of fresh and set gray MTA, without any difference between them. Saidon et al. (14) and Haglung et al. (15) found denatured proteins and dead cells underneath fresh MTA samples, morphological changes around them and viable cells in most of the area of the well. The present study obtained similar results for the 48-h set MTA, in agreement with Koulaouzidou et al. (16) who observed little cytotoxicity of 48-h set gray MTA.

Although gray and white MTA cements are slightly cytotoxic and have exhibited similar effects on the cells in the present study, it was interesting to note that during the microscopic analysis the cell behavior in the presence of ProRoot MTA was the most favorable.
Accordingly, Pérez et al. (17) and Camilleri et al. (18) showed less cell growth in the presence of white MTA, but they confirmed its biocompatibility.

Epoxy resin has a favorable property of adhesion to dental structure and calcium hydroxide is known to be biocompatible (19). Cohen et al. (10) demonstrated severe cytotoxicity of resin-based cements in the first $48 \mathrm{~h}$ after preparation, period in that the most toxic substances are released from resin-based cement, according to the same authors. The present investigation revealed grade 2 (mild) for 48-h set MBPc, probably because the cement had been left to set for $48 \mathrm{~h}$ before it has been used, which reduced its toxicity in a considerable way (20). Even though our morphological findings showed that fibroblasts appeared rounded, unstained and probably in the process of apoptosis in the greatest part of the discolored area as an effect of MBPc, only close to the cement the cells presented vacuolated cytoplasms or lysis, differently from positive controls that determined the entire discolored area with dead cells.

ProRoot MTA and Angelus WMTA were slightly cytotoxic. Although the experimental MBPc was the most cytotoxic cement among the 3 tested, the sample was considered satisfactory. The changes in cell morphology occurred in the following sequence of intensity:
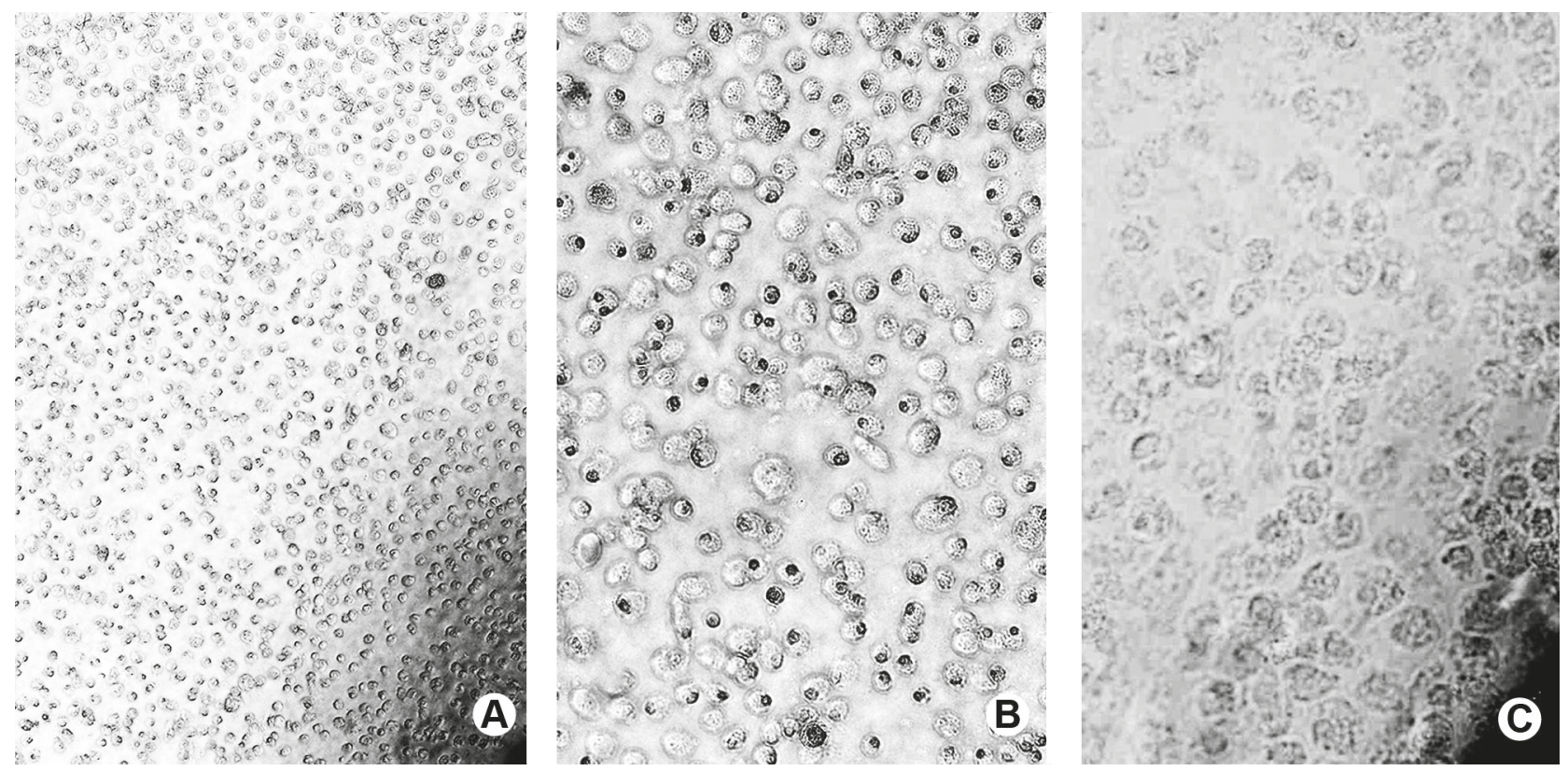

Figure 3. Discolored area into well 3 of MBPc: a) lysis zone $(\times 100$ magnification $)$; $b)$ rounded cells loosened from the substrate $(\times 200$ magnification); c) dead cells around the cement $(\times 400$ magnification $)$. 
gray ProRoot MTA $<$ Angelus WMTA $<$ MBPc, considering that the changes associated with the positive controls were significantly more intense than those observed these materials.

A further biochemical evaluation would be interesting to count viable cells after contact with the tested materials. The experimental MBPc cement must be subjected to other tests to allow an appropriate clinical indication of its biocompatibility. This material may become a good alternative to repair root perforations.

\section{RESUMO}

O objetivo deste estudo foi comparar a citotoxicidade de um cimento experimental à base de resina epóxica e hidróxido de cálcio (MBPc), do agregado trióxido mineral (MTA) cinza e do MTA branco, utilizando o ensaio de difusão em agar com o corante vermelho neutro. Células L929 foram semeadas em placas de 6 poços e sobre elas a camada de agar, onde foram colocados os materiais endurecidos por $48 \mathrm{~h}$, em triplicata, além de teflon como controle negativo e látex como controle positivo. Após 24 $\mathrm{h}$ em estufa umidificada a $37^{\circ} \mathrm{C}$ com $5 \% \mathrm{CO}_{2}$, um halo claro se formou ao redor das amostras e dos controles positivos. As medidas foram tomadas, por quadrante, e as médias foram comparadas e convertidas em graus para qualificar os resultados, de acordo com a tabela de grau de citotoxicidade do POP/FIOCRUZ. As zonas de inibição e as alterações da morfologia celular foram avaliadas sob microscópio invertido. Os resultados revelaram grau 1 (leve) para os dois tipos de MTA ( $>0,05)$ e grau 2 (branda) para o MBPc $(p<0,001)$. Todas as amostras foram consideradas satisfatórias, pois nenhuma cultura exposta aos cimentos revelou toxicidade superior ao grau 2.

\section{ACKNOWLEDGEMENTS}

This study was supported in part by the National Institute of Health Quality (INCQS)/ Oswaldo Cruz Foundation (FIOCRUZ, RJ, Brazil). The authors thank Dr. Ivaldo Gomes de Moraes for supply of MBPc.

\section{REFERENCES}

1. Lee SJ, Monsef M, Torabinejad M. Sealing ability of a mineral trioxide aggregate for repair of lateral root perforations. J Endod 1993;19:541-544.

2. Oliveira MG, Xavier CB, Demarco FF, Pinheiro ALB, Costa AT, Pozza DH. Braz Dent J 2007;18:3-7.

3. Asgary S, Parirokh M, Eghbal MJ, Brink F. Chemical differences between white and gray mineral trioxide aggregate. J Endod 2005;31:101-103.
4. Faraco Júnior IM, Holland R. Histomorphological response of dogs'dental pulp capped with white mineral trioxide aggregate. Braz Dent J 2004;15:104-108.

5. Al-Rabeah E, Perinpanayagam H, Macfarland D. Human alveolar bone cells interact with ProRoot and tooth-colored MTA. J Endod 2006;32:872-875.

6. Silva Neto UX, Moraes IG. Sealing capacity produced by some materials when utilized under furcation perforations of extract human molars. J Appl Oral Sci 2003;11:27-33.

7. Desai S, Chandler N. Calcium hydroxide-based root canal sealers: a review. J Endod 2009;35:475-480.

8. Orosco FA, Bramante CM, Garcia RB, Bernardineli NB, Moraes IG. Sealing ability of gray MTA Angelus ${ }^{\mathrm{TM}}, \mathrm{CPM}^{\mathrm{TM}}$ and $\mathrm{MBPc}$ used as apical plugs. J Appl Oral Sci 2008;16:50-54.

9. Cintra LTA, Moraes IG, Bernabé PFE, Gomes-Filho JE, Bramante $\mathrm{CM}$, Garcia Rb, et al.. Evaluation of the tissue response to MTA and MBPc: microscopic analysis of implants in alveolar bone of rats. J Endod 2006;32:556-559.

10. Cohen BI, Pagnillo BS, Musikant BL, Deutsch AS. An in vitro study of the cytotoxicity of two root canal sealers. J Endod 2000;26:228-229.

11. Standard Operating Procedures (SOP)/Quality Brochure. Rio de Janeiro: INCQS/FIOCRUZ. (65.3330.010). In vitro cytotoxicity assay - Agar diffusion method (In Portuguese). 2000. 17 p.

12. Koh ET, McDonald F, Pitt Ford TR, Torabinejad M. Cell response to mineral trioxide aggregate. J Endod 1998;24:543-547.

13. Torabinejad M, Hong CU, Pitt Ford TR, Kettering JD. Cytotoxicity of four root end filling materials. J Endod 1995;21:489-492.

14. Saidon J, He J, Zhu WQ, Safavi K, Spångberg LZW. Cell and tissue reactions to mineral trioxide aggregate and Portland cement Oral Surg Oral Med Oral Pathol Oral Radiol Endod 2003;95:483489.

15. Haglung R, Safavi KE, Zhu Q. Effects of root-end filling materials on fibroblasts and macrophages in vitro. Oral Surg Oral Med Oral Pathol Oral Radiol Endod 2003;95:739-745.

16. Koulaouzidou EA, Papazisis KT, Economides NA, Panagiotis $\mathrm{B}$, Kortisaris AH. Antiproliferative effect of mineral trioxide aggregate, zinc oxide-eugenol cement, and glass-ionomer cement against three fibroblastic cell lines. J Endod 2005;31:44-46.

17. Pérez AL, Spears R, Gutmann JL, Opperman LA. Osteoblasts and MG-63 osteosarcoma cells behave differently when in contact with ProRoot ${ }^{\mathrm{TM}}$ MTA and white MTA. Int Endod J 2003;36:564-570.

18. Camilleri J, Montesin FE, Papaioannu S, McDonald F, Pitt Ford TR. Biocompatibility of two commercial forms of mineral trioxide aggregate. Int Endod J 2004;37:699-704.

19. Schwarze T, Fiedler I, Leyhausen G, Geurtsen W. The cell compatibility of five endodontic sealers during the setting period. J Endod 2002;28:784-786.

20. Huang FM, Tai KW, Chou MY, Chang YC. Cytotoxicity of resin-, zinc oxide-eugenol-, and calcium hydroxide-based root canal sealers on human periodontal ligament cells and permanent V79 cells. Int Endod J 2002;35:153-158.

Accepted February 1, 2009 